ARTICLE HISTORY: Received: September 04, 2021 Accepted: October 28, 2021 Published: November 03, 2021

АККУМУЛЯЦИЯ ЖЕЛЕЗА И МАРГАНЦА В ЛИСТЬЯХ СОСНЫ ОБЫКНОВЕННОЕ И
ТРАВЯНИСТОГО ПОКРОВА БЕСКАРАГАЙСКОГО ЛЕНТЧНОГО БОРА КАЗАСТАНА

\author{
Жумадина Шолпан Молдажановна \\ док.биол. наук, и.о.профессор кафедры «Биологические науки» \\ НАО Казахского агротехнического университета им. С. Сейфуллина, \\ 010011 , г. Казахстан, Нур-Султан, пр. Женис 62 \\ Булекбаева Ляззат Токсановна \\ кан.биол. наук, доцент кафедры «Биологические науки» \\ НАО Казахского агротехнического университета им. С. Сейфуллина, \\ 010011, Казахстан, г. Нур-Султан, пр. Женис 62
}

\title{
ACCUMULATION OF IRON AND MANGANESE IN THE LEAVES OF PINE PINE AND HERBAL COVER OF THE BESKARAGAY TAPE BORON OF KAZASTAN
}

\author{
Zhumadina Sholpan \\ doc. biol. Sciences, Acting Professor of the Department of \\ "Biological Sciences" of the NAO Kazakh Agrotechnical University named after S. Seifullin, \\ 010011, Kazakhstan, Nur-Sultan, Zhenis Ave. 62 \\ Bulekbaeva Lyazzat \\ can.biol. Sci., Associate Professor of the Department of Biological Sciences, \\ AO Kazakh Agrotechnical University named after S. Seifullina \\ 010011, Kazakhstan, Nur-Sultan, Zhenis Ave. 62
}

\begin{abstract}
Аннотация. В работе изложены материалы по изучению и содержанию накопления железа и марганца в древесных и травянистых листьях Бескарагайского ленточного бора сухостепной зоны Казахстана, а также соотношение железа и марганца для определения условия нормальной жизнедеятельности растений.

Результаты исследований показали, что значения показателя биотичности в древесных и травянистых растениях Бескарагайского лентчоного бора для железа составляют ниже 0,3 . В хвоинках сосен ни в одной из зон не сохранено соотношение между железом и марганцем для нормальной жизнедеятельности сосновых растений. Аккумуляция марганца в травах происходит в основном из атмосферы. Из двух биогенных металлов, роль биогеохимического круговорота веществ для хвоинок сосны выполняет только Мn в Бескарагайском бору. Значения $K_{\text {н }}$ железа меньше одного в хвоинках сосен, взятых из различных зон Бескарагайского леса, что указывает на поступление марганца, в лесные экосистемы, как из почвы, так и из атмосферы. Соотношение концентрации железа и марганца $2: 1$, необходимое травам для нормальной жизнедеятельности наблюдается только в зоне грунтовых дорог Бескарагайского леса. Работа имеет большое значение для дальнейшего мониторинга состояния лесных экосистем в условиях техногенного и аэротехногенного загрязнения исследуемой территории.
\end{abstract}

Abstract. The paper presents materials on the study and content of the accumulation of iron and manganese in the woody and herbaceous leaves of the Beskaragai belt pine forest of the dry steppe zone of Kazakhstan, as well as the ratio of iron and manganese to determine the conditions for normal plant life.

The results of the research showed that the values of the biotic index in woody and herbaceous plants of the Beskaragay lentchen boron for iron are below 0.3. In the needles of pine trees, none of the zones retained the ratio between iron and manganese for the normal life of pine plants. The accumulation of manganese in herbs occurs mainly from the atmosphere. Of the two biogenic metals, only $\mathrm{Mn}$ in the Beskaragai pine forest plays the role of biogeochemical circulation of substances for pine needles. The values of $\mathrm{KH}_{\mathrm{H}}$ for iron are less than one in pine needles taken from different zones of the Beskaragai forest, which indicates the input of manganese into forest ecosystems, both from the soil and from the atmosphere. The ratio of the concentration of iron and manganese 2: 1, which is necessary for grasses for normal life, is observed only in the zone of unpaved roads of the Beskaragai forest. The work is of great importance for further monitoring of the state of forest ecosystems in the conditions of technogenic and aeronautical pollution of the study area.

Ключевые слова: биогенные элементы, аккумуляция, древесные и травянистые растения

Key words: nutrients, accumulation, woody and herbaceous plants

\section{Введение}


Сосновые боры Семипалатинского Прииртышья - это реликтовые леса, выполняющие климаторегулирующие, санитарно - гигиенические, почвозащитные функции, в пределах региона являются единственными преградами песчаным бурям. Общая площадь сосновых лесов Республики Казахстан составляет 832 тыс. га, из которых 545 тыс. га (58\%) приходится на ленточные боры Прииртышья. Для нормального функционирования и жизнедеятельности живых организмов, в том числе и растений, важное значение имеет содержание биогенных элементов, таких как железо и марганец, относящихся к III группе опасности [1]. Необходимым условием длительного существования лесных экосистем, как и любых природных экосистем, является стабильность биогеохимического круговорота веществ.

Важнейшей экологической проблемой современности, возрастающей с каждым годом, является загрязнение окружающей среды тяжелыми металлами (ТМ). Поступление ТМ в атмосферу оказывает негативное воздействие на почвы и растения, и представляет угрозу для здоровья человека [1].

В настоящее время нет единого мнения о степени опасности тяжелых металлов для растительных организмов. К особо опасным тяжелым металлам для древесной растительности, в случае их накопления, некоторые исследователи относят кобальт, медь, свинец, цинк, кадмий, ртуть [2]. По мнению А. КабатаПендиас, Х. Пендиас [3] наиболее ядовитыми для высших растений, являются также ртуть, медь, свинец, кобальт, кадмий и никель. Российский санитарно-гигиенический ГОСТ 17.4.102-83 к высокоопасным элементам относит - Zn, Cd, к умеренноопасным - Ni и Мо. Программой ООН по окружающей среде (ЮНЕП) к наиболее опасным веществам отнесены Со и V.

Наиболее опасными токсичными тяжелыми металлами являются, как известно, элементы $\mathrm{Hg}, \mathrm{Pb}, \mathrm{Cd}, \mathrm{Zn}$, $\mathrm{As}, \mathrm{Se}, \mathrm{Be}$, относящиеся к I группе опасности. Для нормального функционирования и жизнедеятельности живых организмов, в том числе и растений, важное значение имеет содержание биогенных элементов, таких как железо и марганец, относящихся к III группе опасности. Железо играет ведущую роль среди всех содержащихся в растениях тяжелых металлов. Среднее содержание железа в растениях составляет 0,02-0,08\% (20-80 мг/кг сухой массы). Марганец принимает активное участие в обмене веществ, улучшает физиологические процессы. Среднее его содержание в растениях составляет 0,001\%, (1 мг/кг сухой массы) тканей [1]. Необходимым условием длительного существования лесных экосистем, как и любых природных экосистем, является стабильность биогеохимического круговорота веществ.

Как показал анализ литературных источников, вопросом влиянии ТМ на экологическое состояние природных лесных ландшафтов и лесных насаждений в городах Казахстана, занимаются пока очень мало авторов [4-9]. Целью работы явилось изучение накопление железа и марганца в древесных и травянистых листьях ленточных боров сухостепной зоны Бескарагая (ВКО), а также соотношение железа и марганца для определения условия нормальной жизнедеятельности растений.

\section{Материалы и методы исследований}

Объектом исследования были выбраны почвы, древесные и травянистые растения Бескарагайского ленточного бора, относящихся к резерватам «Семей орманы», расположенных в Восточно-Казахстанской областей. По данным Казахского научно-исследовательского института лесного хозяйства и агролесомелиорации Республики Казахстан исследуемые леса относятся к району сухостепных Прииртышских ленточных сосновых боров. Содержание и соотношение биогенных элементов в древесных и травянистых растениях ленточного бора Бескарагая исследовали в зонах барханы, естественные равнины, антропогенные участки и возле грунтовых дорог.

Содержание биогенных элементов определяли в аккредитованной лаборатории ТОО «Эко НУС» (г. Караганда) на атомно-эмиссионом спектрометре с индуктивно-связанной плазмой марки SPECTRO ARCOS (Германия).

Для оценки плотности биогеохимической связи состава живого организма с биосферой были расчитаны значения ПБЭ в листьях древесных и травянистых растений, показывающий отношение концентрации элемента в листьях к кларку земной коры [1]:

$$
\text { ПБЭ }=\mathrm{C}_{\mathrm{p}} / \mathrm{K}_{\text {лит }}
$$

где $\mathrm{C}_{\mathrm{p}}$ - общее содержание элемента в растениях, мг/кг;

$\mathrm{K}_{\text {лит }}-$ кларк элемента в литосфере, мг/кг.

В расчетах мы использовали данные А.П. Виноградова [10], которые приведены ниже.

$\begin{array}{ccc}\text { Элемент } & \mathrm{Fe} & \mathrm{Mn} \\ \text { кларк элемента } & 51000,00 & 900,00\end{array}$

Аккумуляцию химических элементов в листьях древесных и травянистых растений оценивали с помощью коэффициента концентрации $\left(\mathrm{K}_{\mathrm{c}}\right)$, который представляет собой отношение содержания элемента в листьях 
растений к его концентрации в листьях, произрастающих на фоновых участках [11]. Некоторые авторы это соотношение называют коэффициентом аккумуляции $\left(\mathrm{K}_{\mathrm{a}}\right)$ [7].

$$
\mathrm{K}_{\mathrm{c}}=\mathrm{C}_{\mathrm{p}} / \mathrm{C}_{\phi},
$$

где $\mathrm{C}_{\mathrm{p}}$ - концентрация ТМ в сухой массе растений, мг/кг;

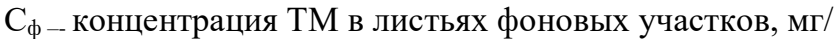

Для характеристики распределения элементов между живым веществом и абиотической средой определяли коэффициенты накопления $\left(K_{\mathrm{H}}\right)$. $\mathrm{K}_{\mathrm{H}}$ - отношение концентрации ТМ в сухой массе растений (мг/кг) к концентрации ТМ подвижной формы в почве (мг/кг) [1]. Авторы [7] такой коэффициент называют индексом аккумуляции и обозначают его через $\mathrm{I}_{\mathrm{a}}$.

$$
\mathrm{K}_{\mathrm{H}}=\mathrm{C}_{\mathrm{p}} / \mathrm{C}_{\mathrm{n}},
$$

где $\mathrm{C}_{\mathrm{p}}$ - концентрации ТМ в сухой массе растений, мг/кг;

$\mathrm{C}_{\text {п }}$ - концентрации ТМ подвижной формы в почве, мг/кг.

Коэффициент опасности $\left(\mathrm{K}_{\mathrm{o}}\right)$ представляет отношение содержания металла в почве или растениях к предельно допустимой концентрации металла в почве или растениях [9].

$$
\kappa_{\mathrm{o}}=\mathrm{C}_{\Pi / \mathrm{p}} / \Pi Д К_{\Pi / \mathrm{p}},
$$

где $\mathrm{C}_{\text {п/p }}-$ концентрация металла в почве или в растениях,

ПДК ПДК берем критическую концентрацию.

Результаты собственных исследований

Ермаков В.В. и др. [12] считают, что уровни содержания элементов в растениях в качестве экологических критериев выбираются ввиду того, что в биогеохимической пищевой цепи растения занимают центральное место. В таблице 1 мы привели заимствованные из [12] данные о содержании химических элементов в наземных растениях по данным различных исследователей [13-16].

Таблица 1

Среднее содержание химических элементов в наземных растениях по данным различных авторов, мг/кг

\begin{tabular}{|c|c|c|c|c|}
\hline Химический элемент & {$[13]$} & {$[14]$} & {$[15]$} & {$[16]$} \\
\hline $\mathrm{Fe}$ & 140 & 200 & $50-1000$ & 150 \\
\hline $\mathrm{Mn}$ & 630 & 240 & $20-500$ & 200 \\
\hline
\end{tabular}

В таблице 2 показаны результаты химического анализа по содержанию и соотношению железа и марганца в древесных растениях Бескарагайского бора. Как видно из данных таблицы 2 , концентрация железа ни в одной из зон не превышает критическую, в случае же марганца этого сказать нельзя, так как его концентрация превышает ПДК. Значение К для хвоинок сосны чуть выше единицы только в случае антропогенной зоны, максимальное значение 1,98 - в зоне грунтовых дорог. В зонах барханов и естественных равнин это значение колеблется в пределах $1,2-1,4$.

Таблица 2

\begin{tabular}{|c|c|c|c|c|c|c|}
\hline \multirow[b]{3}{*}{ Зоны } & \multicolumn{5}{|c|}{ Элемент } & \multirow{3}{*}{$\begin{array}{c}\text { Cо } \\
\text { отно } \\
\text { ше } \\
\text { ние } \\
\mathrm{Fe} \\
: \mathrm{Mn}\end{array}$} \\
\hline & \multicolumn{2}{|c|}{ железо } & \multicolumn{3}{|c|}{ марганец } & \\
\hline & $\begin{array}{c}\text { крити } \\
\text { ческая концентрация, } \\
\text { мг/кг }\end{array}$ & $\begin{array}{l}\text { концентра } \\
\text { ция } \\
\text { мГ/кг }\end{array}$ & $\begin{array}{c}\text { ПДК, } \\
\text { мг/кг }\end{array}$ & $\begin{array}{c}\text { ко } \\
\text { нцен } \\
\text { тра } \\
\text { ция } \\
\text { мг/ } \\
\text { кг } \\
\end{array}$ & o & \\
\hline барханы & \multirow{3}{*}{750} & 576,25 & \multirow{3}{*}{300} & $\begin{array}{c}36 \\
3,30\end{array}$ &, $21^{1}$ & $\begin{array}{l}1,6 \\
: 1,0\end{array}$ \\
\hline $\begin{array}{l}\text { естественные } \\
\text { равнины }\end{array}$ & & 511,65 & & $0,00^{42}$ &, $40^{1}$ & $1,2: 1,0$ \\
\hline антропогенные & & 426,46 & & 32 & & \\
\hline
\end{tabular}

Содержание и соотношение биогенных элементов в древесных растениях ленточного бора Бескарагая по зонам 


\begin{tabular}{|c|c|c|c|c|c|c|}
\hline & & & 0,60 &, 07 & $1,3: 1,0$ \\
\cline { 5 - 7 } & & \multirow{2}{*}{247,25} & & 59 & 1 & \\
\cline { 5 - 7 } & & & 3,30 &, 98 & $0,1,0$ \\
\hline
\end{tabular}

Сравнение данных таблиц 1 и 2 показывает, что содержание железа укладывается в пределы, указанных автором [15], но максимальное содержание марганца не соответствует данным ни одного из авторов. Такое явление авторы [12] связывают с тем, что значительные изменения среднего содержания химического состава растений зависят не только от методического различия определения концентрации элементов, но и от специфики аккумулирования их организмами.

Марганец накапливается в листьях. Избыток марганца, так же, как и его недостаток, неблагоприятно сказывается на растениях. Многочисленные исследования показали наличие определенной зависимости между содержанием железа и марганца. Для нормальной жизнедеятельности растений концентрация железа и марганца должны находиться в соотношении (примерно 2:1) [3, 17,18]. В нашем случае ни в одной зоне такого соотношения между двумя биогенными элементами не соблюдается. Отсюда можно прийти к заключению, что в Бескарагайском ленточном бору не сохранены соотношения для нормальной жизнедеятельности сосновых растений.

Теперь последовательно рассмотрим результаты расчетов всех показателей по древесным листьям. Данные расчета ПБЭ сосновых листьев по формуле 1 приведены в таблице 3.

Таблица 3

Результаты расчета показателя биотичности элементов в древесных листьях Бескарагайского бора по зонам

\begin{tabular}{|c|c|c|c|c|}
\hline \multirow{2}{*}{$\begin{array}{c}\text { Тяже } \\
\text { лый металл }\end{array}$} & \multicolumn{4}{|c|}{ ПБЭ по зонам } \\
\cline { 2 - 5 } & барханы & естественные равнины & антропогенные & $\begin{array}{c}\text { вдоль грунтовых } \\
\text { дорог }\end{array}$ \\
\hline $\mathrm{Fe}$ & 0,011 & 0,010 & 0,008 & 0,005 \\
\hline $\mathrm{Mn}$ & 1,81 & 0,466 & 0,35 & 0,659 \\
\hline
\end{tabular}

ПБЭ прямо пропорционален интенсивности поглощения элементов растениями. Элементы с ПБЭ $\geq 0,3$ выполняют большую роль в биогеохимическом круговороте веществ в лесных экосистемах. Необходимым условием длительного существования лесных, как любых природных экосистем, является стабильность биогеохимического круговорота веществ [8]. Как видно из данных таблицы 3, ПБЭ для железа на порядок ниже, чем вышестоящее значение. А значение ПБЭ для марганца находится в пределах $0,35-1,81$. Таким образом, из двух исследованных биогенных металлов, роль биогеохимического круговорота веществ выполняет только Мn.

Расчет $\mathrm{K}_{\mathrm{c}}$ для сосновых листьев производили по формуле 2, данные показаны в таблице 4.

Из данных таблицы 4 видно, что для железа $\mathrm{K}_{\mathrm{c}}<1$ во всех исследуемых зонах. Для марганца значение этого коэффициента больше единицы в зоне естественных равнин и вдоль грунтовых дорог. Это означает, что в этих зонах имеет место аэротехногенного загрязнения марганцем [19].

Значения коэффициента концентрации $\left(K_{c}\right)$ тяжелых металлов

Таблица 4 в древесных листьях Бескарагайского бора по зонам

\begin{tabular}{|c|c|c|c|c|}
\hline \multirow{2}{*}{$\begin{array}{c}\text { Тяжелые } \\
\text { металлы }\end{array}$} & $\begin{array}{c}\text { Содержание элемента } \\
\text { на фоновом участке }\end{array}$ & $\begin{array}{c}\text { естественные } \\
\text { равнины }\end{array}$ & $\begin{array}{c}\text { антропогенны } \\
\text { е }\end{array}$ & $\begin{array}{c}\text { вдоль грунтовых } \\
\text { дорог }\end{array}$ \\
\hline железо & 576,25 & 0,88 & 0,74 & 0,43 \\
\hline марганец & 363,30 & 1,15 & 0,88 & 1,63 \\
\hline
\end{tabular}

Данные содержания биогенных элементов подвижной формы в почвах Бескарагайского ленточного бора, необходимых для расчета $K_{\text {н }}$ по формуле 3 ), сведены в таблицу 5. Исходя из данных таблицы 5, можно сказать, что концентрация марганца в почвах не представляет никакой опасности, а К (формула 4) для железа имеет значение от 1,01 до 1,18 в зависимости от зоны. Только в почвах зоны грунтовых дорог железо не представляет опасности для древесных растений.

Таблица 5

Содержание биогенных элементов в почве ленточных боров Бескарагая по зонам

\begin{tabular}{|c|c|c|c|}
\hline \multirow{2}{*}{ Зоны } & \multicolumn{3}{|c|}{ Элемент } \\
\cline { 2 - 4 } & железо & & марганец \\
\hline
\end{tabular}




\begin{tabular}{|c|c|c|c|c|c|}
\hline & $\begin{array}{c}\text { ПДК, } \\
\text { мг/кг }\end{array}$ & $\begin{array}{c}\text { концентра } \\
\text { ция, } \\
\text { мг/кГ }\end{array}$ & $\mathrm{K}_{\mathrm{o}}$ & $\begin{array}{r}\text { ПД } \\
\text { К, мг/кг }\end{array}$ & $\begin{array}{l}\text { концентра } \\
\text { ция, мг/кг }\end{array}$ \\
\hline барханы & \multirow{4}{*}{$38000^{*}$} & 38408,96 & $0^{1,01}$ & \multirow{4}{*}{ * 140} & 22,86 \\
\hline естественные равнины & & 44189,01 & $l_{0}^{1,16}$ & & 28,58 \\
\hline антропогенные & & 44775,10 & $\begin{array}{l}1,18 \\
0\end{array}$ & & 53,62 \\
\hline грунтовые дороги & & 18717,43 & - & & 28,48 \\
\hline
\end{tabular}

*- по данным Подлужной А.С. [20]

Результаты расчета коэффициента накопления железа и марганца хвоинок сосны приведены в таблице 6.

Таблица 6

Коэффициент накопления железа и марганца в древесных листьях Бескарагайского леса

\begin{tabular}{|c|c|c|c|c|}
\hline \multicolumn{5}{|c|}{ Значение $K_{\text {н }}$} \\
\hline Тяжелый металл & барханы & естественные равнины & антропогенные & вдоль грунтовых дорог \\
\hline $\mathrm{Fe}$ & 0.015 & 0.01 & 0.01 & 0.013 \\
\hline $\mathrm{Mn}$ & 15,9 & 14,7 & 6,0 & 20,8 \\
\hline
\end{tabular}

По данным таблицы 6 значения $\mathrm{K}_{\mathrm{H}}$ железа меньше одного в хвоинках сосен, взятых из различных зон. В случае марганца этот показатель превышает единицу от 6 до 21 раза. Следовательно, если лесные деревья железо поглощают только из почвы, то марганец поступает еще и из атмосферы [19].

В таблице 7 показаны результаты химического анализа по содержанию железа и марганца и их соотношению травянистых листьев Бескарагайского бора. Как видно из данных таблицы 7, концентрация железа превышает критическую в зонах барханов и антропогенной, в зоне барханов значение К 0 для хвоинок сосны чуть выше единицы, в антропогенной зоне это значение составляет уже 1,4. Концентрация марганца во всех зонах ниже ПДК.

Сравнивая данные таблиц 1 и 7 можно увидеть, что содержание марганца соответствует данным автора [15], концентрация железа вроде бы и укладывается в пределы, указанных этим же автором, но максимальное содержание его в антропогенной зоне чуть выше верхнего предела.

Содержание железа в травах намного превосходит концентрацию марганца по трем первым зонам и соотношение железа и марганца находится в пределах 3,4-3,9:1,0 и 5,2 :1,0 (максимум в антропогенной зоне). Соотношение концентрации железа и марганца 2:1, необходимое растениям для нормальной жизнедеятельности наблюдается только в зоне грунтовых дорог.

Таблица 7

Содержание и соотношение биогенных элементов в травянистых растениях ленточного бора Бескарагая

\begin{tabular}{|c|c|c|c|c|c|c|}
\hline \multirow[b]{3}{*}{ Зоны } & \multicolumn{5}{|c|}{ Элемент } & \multirow[b]{3}{*}{$\begin{array}{l}\text { Соотно } \\
\text { шение } \\
\mathrm{Fe}: \mathrm{Mn}\end{array}$} \\
\hline & \multicolumn{3}{|c|}{ железо } & \multicolumn{2}{|c|}{ марганец } & \\
\hline & $\begin{array}{c}\text { крити } \\
\text { ческая } \\
\text { концентрация, } \\
\text { мг/кг }\end{array}$ & $\begin{array}{c}\text { Концент } \\
\text { рация } \\
\text { мг/кг }\end{array}$ & $\mathrm{K}_{\mathrm{o}}$ & $\begin{array}{l}{ }^{\Pi}, \\
\text { МГ } \\
\text { /Кг }\end{array}$ & $\begin{array}{c}\text { конц } \\
\text { ен } \\
\text { трац } \\
\text { ия, } \\
\text { мг/к } \\
\text { г }\end{array}$ & \\
\hline барханы & \multirow{4}{*}{750} & 868,2 & 1,15 & \multirow{4}{*}{$0^{30}$} & $\begin{array}{l}220, \\
8\end{array}$ & $3,9: 1,0$ \\
\hline естественные равнины & & 683,5 & - & & $\begin{array}{l}199, \\
4\end{array}$ & $3,4: 1,0$ \\
\hline антропогенные & & 1042,0 & 1,40 & & $\begin{array}{l}199 \\
7\end{array}$ & $5,2: 1,0$ \\
\hline грунтовые дороги & & 534,1 & - & & $\begin{array}{l}277, \\
4\end{array}$ & $1,9: 1,0$ \\
\hline
\end{tabular}


Сопоставление концентраций железа и марганца в древесных и травянистых листьях по данным таблиц 2 и 7 показывает, что содержание железа больше в травянистых, а марганца больше в древесных листьях и это изображено на рисунке 1.

Перейдем к анализу расчетов различных показателей для травянистых листьев. Результаты расчетов ПБЭ по зонам ленточного бора показаны в таблице 8. По данным таблицы 8 легко увидеть, что также как в древесных, в травянистых листьях показатели биотичности тоже на порядок ниже для железа по всем зонам и находится в прелах 0,01-0,02. Марганец принимает участие в биогеохимическом круговороте только в зоне грунтовых дорог (ПБЭ=0,31), так как в остальных зонах этот показатель имеет значение ниже $0,3(0,22-0,24)$.

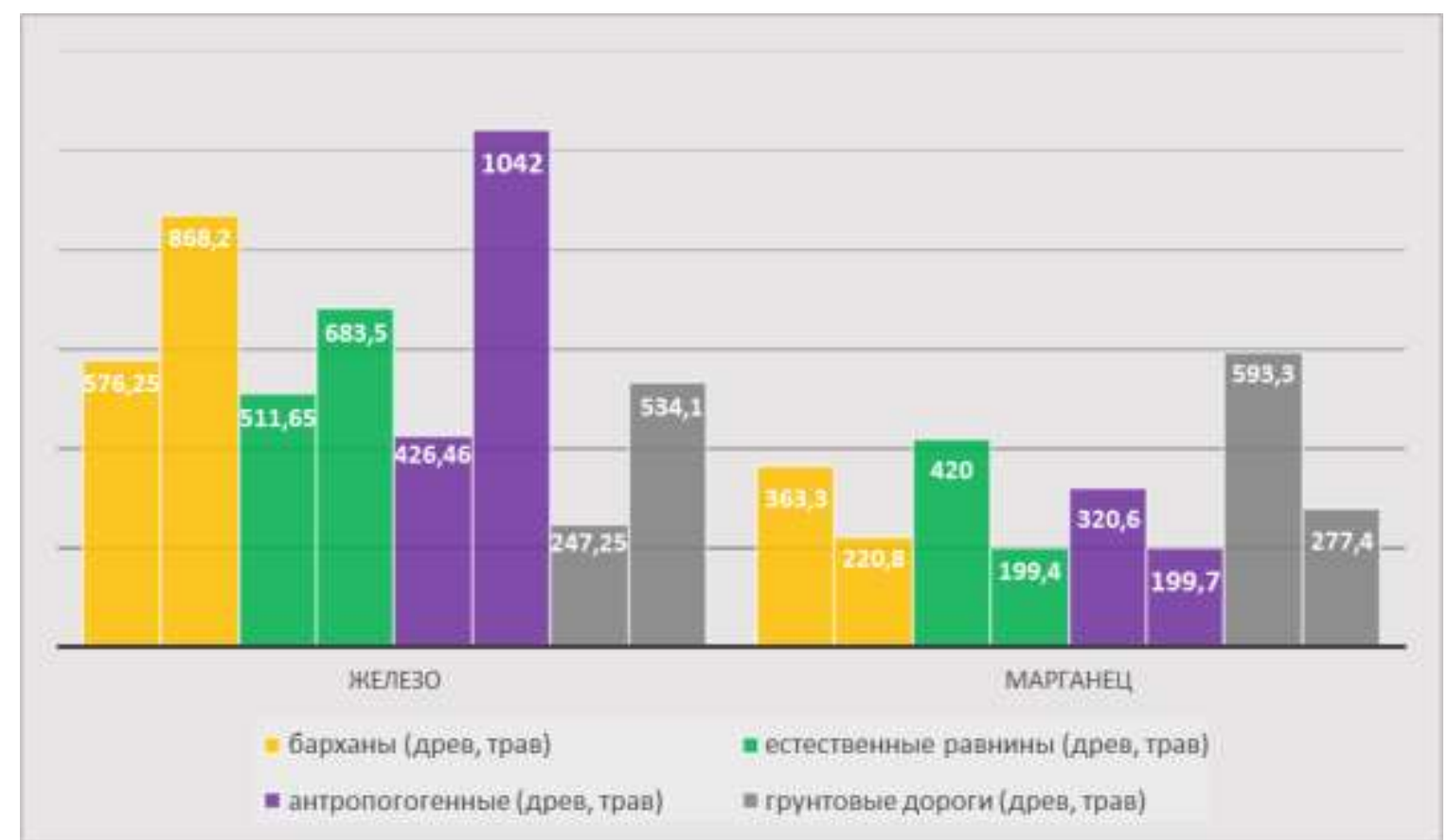

Рисунок 1 - Диаграмма содержания железа и марганиа в листьях древеесных и травянистых растений Бескарагайского соснового бора

Таблица 8

Результаты расчета показателя биотичности элементов в травянистых листьях Бескарагайского бора по зонам

\begin{tabular}{|c|c|c|c|c|}
\hline \multirow{2}{*}{ Тяжелый металл } & \multicolumn{4}{|c|}{ ПБЭ по зонам } \\
\cline { 2 - 5 } & барханы & естественные равнины & $\begin{array}{c}\text { вдоль } \\
\text { автотрассы }\end{array}$ & $\begin{array}{c}\text { вдоль грунтовых } \\
\text { дорог }\end{array}$ \\
\hline $\mathrm{Fe}$ & 0,017 & 0,013 & 0,02 & 0,01 \\
\hline $\mathrm{Mn}$ & 0,24 & 0,22 & 0,22 & 0,308 \\
\hline
\end{tabular}

Расчеты Кс железа и марганца для трав по зонам приведены в таблице 9. Из данных таблицы 9 видно, что Кс $>1$ только в двух случаях: вдоль автотрассы по железу и вдоль грунтовых дорог по марганцу. Это означает, что в этих зонах в травяной покров оба металла поступают как из почвы, так и из атмосферы.

Таблица 9

Значения коэффициента концентрации $\left(\mathrm{K}_{c}\right)$ тяжелых металлов в травянистых листьях Бескарагайского

\begin{tabular}{|c|c|c|c|c|}
\hline \multirow{2}{*}{$\begin{array}{c}\text { Тяжелые } \\
\text { металлы }\end{array}$} & \multirow{2}{*}{$\begin{array}{c}\text { Содержание элемента на } \\
\text { фоновом участке }\end{array}$} & $\begin{array}{c}\text { Естествен } \\
\text { ные } \\
\text { равнины }\end{array}$ & $\begin{array}{c}\text { Вначения } \mathrm{K}_{\mathrm{c}} \\
\text { автотрассы }\end{array}$ & $\begin{array}{c}\text { Вдоль } \\
\text { грунтовых дорог }\end{array}$ \\
\hline железо & 868,25 & 0,79 & 1,20 & 0,61 \\
\hline марганец & 220,80 & 0,90 & 0,90 & 1,26 \\
\hline
\end{tabular}



10.

Результаты расчетов коэффициента накопления железа и марганца травянистого покрова сведены в таблицу

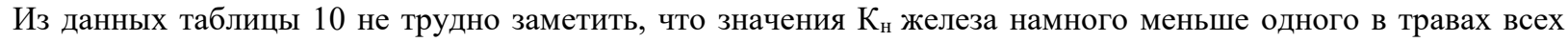
зон, чего нельзя сказать о коэффициенте накопления марганца.

Таблица 10

Коэффициент накопления железа и марганца в травянистых листьях Бескарагайского леса

\begin{tabular}{|c|c|c|c|c|}
\hline \multicolumn{5}{|c|}{ Значение $K_{\text {н }}$} \\
\hline Тяжелый металл & барханы & естественные равнины & $\begin{array}{c}\text { вдоль } \\
\text { автотрассы }\end{array}$ & вдоль грунтовых дорог \\
\hline $\mathrm{Fe}$ & 0.02 & 0.015 & 0.02 & 0.03 \\
\hline $\mathrm{Mn}$ & 9,65 & 6,97 & 3,72 & 9,74 \\
\hline
\end{tabular}

К для марганца колеблется в пределах 3,7- 9,7 в зависимости от зоны сбора трав, то есть травяной покров аккумулирует марганец в основном из атмосферы [19].

Выводы

1. Результаты химического анализа по содержанию железа и марганца в древесных растениях по зонам Бескарагайского бора показали, что в фоновой зоне содержание этих элементов выше, чем в остальных. Концентрация железа ни в одной из зон не превышает критическую, а марганца превышает. Коэффициент опасности марганца в антропогенной зоне чуть выше единицы, а в зоне грунтовых дорог $\mathrm{K}_{0}=2$. В зонах барханов и естественных равнин это значение колеблется в пределах 1,2 - 1,4. Соотношение между железом и марганцем ни в одной зоне не соответствуют условию, необходимому для нормальной жизнедеятельности растений.

2. Для железа древесных листьев значение ПБЭ < 0,3 по всем исследованным зонам, а для марганца этот показатель находится в пределах 0,35 - 1,81. Таким образом, из двух исследованных биогенных металлов, роль биогеохимического круговорота веществ для хвоинок сосны выполняет только Mn.

3. Во всех исследуемых зонах для железа хвоинок $\mathrm{K}_{\mathrm{c}}<1$. Для марганца значение этого коэффициента больше единицы в зоне естественных равнин и вдоль грунтовых дорог. Концентрация марганца в почвах не представляет никакой опасности, а К для железа имеет значение от 1,01 до 1,18 в зависимости от зоны. Только в почвах зоны грунтовых дорог железо не представляет опасности для древесных растений. Значения К железа меньше одного в хвоинках сосен, взятых из различных зон. В случае марганца этот показатель превышает единицу от 6 до 21 раза. Видимо, в этих зонах имеет место аэротехногенного загрязнения марганцем.

4. Сопоставление значений концентраций железа и марганца в древесных и травянистых листьях показывает, что содержание железа больше в травянистых, а марганца - в древесных листьях. Концентрация железа превышает критическую в зонах барханов и антропогенной, в зоне барханов значение К для хвоинок сосны чуть выше единицы, в антропогенной зоне это значение составляет уже 1,4. Концентрация марганца во всех зонах ниже ПДК.

5. Содержание железа в травах намного превосходит концентрацию марганца по трем первым зонам и соотношение железа и марганца находится в пределах 3,4-3,9:1,0 и 5,2:1,0 (максимум в антропогенной зоне). Соотношение концентрации железа и марганца 2:1, необходимое травам для нормальной жизнедеятельности наблюдается только в зоне грунтовых дорог.

6. В случае травянистых растений марганец принимает участие в биогеохимическом круговороте только в зоне грунтовых дорог (ПБЭ=0,31). Для железа $\mathrm{K}_{\mathrm{c}}<1$ во всех исследуемых зонах. Для марганца значение этого коэффициента больше единицы в зоне естественных равнин и вдоль грунтовых дорог. Значения К железа

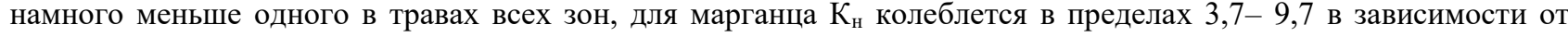
зоны сбора трав, то есть травяной покров аккумулирует марганец в основном из атмосферы.

7. Исследования имеют большое значение для дальнейшего мониторинга состояния лесных экосистем в условиях техногенного и аэротехногенного загрязнения.

Результаты, наших исследований представленные в данной работе, были выполнены в рамках научноисследовательского проекта «Исследование влияния экологических факторов на динамику состояния лесных экосистем в условиях степной зоны Казахстана» при поддержке МОН РК. Полученные данные можно использовать для оценки экологического состояния лесных экосистем при проведении мониторинговых и научно-изыскательских работ. 


\section{Список литературы:}

1. Копылова Л.В. Накопление тяжелых металлов на урбанизированных территориях Восточного Забайкалья: автореферат дис. ... кан-та биол. наук: 03.02.08 /Копылова Л.В. - Улан-Удэ, 2012. - 24c.

2. Григоренко А. В. Влияние аэротехногенного загрязнения на компоненты лесной экосистемы :на примере Минусинского ленточного бора: автореферат дис. ... кан-та биол. наук: 03.02.08 /Григоренко А.В. - Красноярск: СФУ, 2018.- 24c.

3. Кабата-Пендиас А., Пендиас Х. Микроэлементы в почвах и растениях. Пер. с англ. - М.: Мир, 1989. - 439 c.

4. Панин М. С. Миграция тяжелых металлов и пути поступления их в растения // Аккумуляция тяжелых металлов растениями Семипалатинского Прииртышья. - 1999. - С.23-30.

5. Асылбекова Г. Е. Оценка экологического состояния урбоэкосистемы г. Павлодара с использованием растительных объектов: автореферат дис. ... на кан-та биол. наук: Асылбекова Г.Е. -Новосибирск, 2010. - 24c.

6. Панин М.С. Листья древесных растений как биоиндикаторы загрязнения атмосферы города Семей / М.С. Панин, А.Ж. Есенжолова // Экологические системы и приборы, 2011, № 10, С. 43-47.

7. Есенжолова А. Ж. Листья древесных и кустарниковых растений как биоиндикаторы состояния окружающей среды городов Восточного, Северного и Центрального Казахстана: автореферат дис. ... кан-та биол. наук: 03.02.08 /Есенжолова А.Ж. - Новосибирск, 2013.- 20c.

8. Сибиркина А. Р. Биогеохимическая оценка содержания тяжелых металлов в сосновых борах семипалатинского Прииртышья - автореферат дис. ... докт. биол. наук: 03.02 .08 / Сибиркина А.Р. - Омск, 2014. $38 \mathrm{c}$.

9. Галямова Г.К. Биогеохимическая характеристика некоторых древесных культур г. Усть-Каменогорска. авторефрат дис. .... кан-та биол. наук: 03.02 .08 /Галямова Г.К. - Астрахань, 2013. - 24c.

10. Кларковое число. Электронный ресурс: https://ru.wikipedia.org/wiki/ (дата обращения10.10. 2019 г)

11.Ташекова А.Ж., Торопов А.С. Использование листьев растений как биогеохимических индикаторов состояния городской среды // Известия Томского политехнического университета. Инжиниринг георесурсов. 2017. Т.328, №5. С.114-124.

12. Ермаков В.В., Тютиков С.В., Сафонов В.А. Биогеохимическая индикация микроэлементов / Отв. Ред. Т.И. Моисеенко. - Москва, 2018. - 386с.

13. Ковальский В.В. Геохимическая экология. - М.: Наука,1974. - 282c.

14. Романкевич Е.А.Живое вещество Земли (биогеохимические аспекты проблемы) // Геохимия. 1988. №2.C. $292-306$.

15. Kabata-Pendias A., Pendias H. Biogeochemia Pierwlastkov Sladowych. Warzsawa: Wydawnictwo Naukowe PWN, 1999. $400 \mathrm{~s}$.

16. Markert B., Fränzle S., Wünschmann S. Chemical Evolution: The Biological System of the Elements. Springer International Publishing, Switzerland, 2015. - 295 ps.

17. Ильин, В.Б. Микроэлементы и тяжелые металлы в почвах и растениях / В.Б. Ильин, А.И. Сысо. Новосибирск: изд-во СО РАН, 2001. - 229 с.

18. Копылова Л.В. Аккумуляция железа и марганца в листьях древесных растений в техногенных районах Забайкальского края // Известия Самарского научного центра Российской академии наук. 2010.Т.12, № 1-3. С. $709-712$.

19 Ильин В. Б., Степанова М. Д. Защитные возможности системы почва-растения при загрязнении почв ТМ // ТМ в окружающей среде. - М.: МГУ, 1986. - С.80-85.

20. Подлужная А. С. Аккумуляция тяжелых металлов в почве и древесных культурах рекреационных зон г. Красноярска.__ автореферат дис. ... кан-та биол. наук: 03.02 .08 / Подлужная А.С. - Тюмень, 2019. $-18 \mathrm{c}$.

\section{References}

1. Kopylova L.V. Nakopleniye tyazhelykh metallov na urbanizirovannykh territoriyakh Vostochnogo Zabaykal'ya: avtoreferat dis. ... kan-ta biol. nauk: 03.02.08 /Kopylova L.V. - Ulan-Ude, 2012. - 24p.

2. Grigorenko A. V. Vliyaniye aerotekhnogennogo zagryazneniya na komponenty lesnoy ekosistemy :na primere Minusinskogo lentochnogo bora: avtoreferat dis. ... kan-ta biol. nauk: 03.02.08 /Grigorenko A.V. - Krasnoyarsk: SFU, 2018. -24 p.

3. Kabata-Pendias A., Pendias X. Mikroelementy v pochvakh i rasteniyakh. Per. s angl. - M.: Mir, 1989. - 439 p.

4. Panin M.S.Migration of heavy metals and their pathways into plants // Akkymylyatsiya tyazhelyx metallov pacteniyami Cemipalatinckogo Ppiiptysh'ya. - 1999. - pp.23-30.

5. Asylbekova G. Ye. Otsenka ekologicheskogo sostoyaniya urboekosistemy g. Pavlodara s ispol'zovaniyem rastitel'nykh ob"yektov: avtoreferat dis. ... na kan-ta biol. nauk: Asylbekova G.Ye. -Novosibirsk, 2010. - 24p.

6. Panin M.S. Leaves of woody plants as bioindicators of air pollution in the city of Semey / M.S. Panin, A. Zh. Esenzholova // Ekologicheskiye sistemy i pribory, 2011, № 10, pp. 43-47. 
7. Yesenzholova A. ZH. List'ya drevesnykh i kustarnikovykh rasteniy kak bioindikatory sostoyaniya okruzhayushchey sredy gorodov Vostochnogo, Severnogo i Tsentral'nogo Kazakhstana: avtoreferat dis. ... kan-ta biol. nauk: 03.02.08 /Yesenzholova A.ZH. - Novosibirsk, 2013.-20p.

8. Sibirkina A. R. Biogeokhimicheskaya otsenka soderzhaniya tyazhelykh metallov v sosnovykh borakh semipalatinskogo Priirtysh'ya - avtoreferat dis. ... dokt. biol. nauk: 03.02.08 / Sibirkina A.R. - Omsk, 2014. - 38p.

9. Galyamova G.K. Biogeokhimicheskaya kharakteristika nekotorykh drevesnykh kul'tur g. Ust'-Kamenogorska. avtorefrat dis. ... kan-ta biol. nauk: 03.02.08 /Galyamova G.K. - Astrakhan', 2013. - 24p.

10. Klarkovoye chislo. Electronic resource: https://ru.wikipedia.org/wiki/ (date of the application 10.10. 2019 г)

11. Tashekova A.Zh., Toropov A.S. The use of plant leaves as biogeochemical indicators of the state of the urban environment // Izvestiya Tomskogo politekhnicheskogo universiteta. Inzhiniring georesursov. 2017. Vol.328, №5. pp.114-124.

12. Yermakov V.V., Tyutikov S.V., Safonov V.A. Biogeokhimicheskaya indikatsiya mikroelementov / Otv. Red. T.I. Moiseyenko. - Moskva, 2018. - 386p.

13. Koval'skiy V.V. Geokhimicheskaya ekologiya. - M.: Nauka,1974. - 282p.

14. Romankevich E.A. Living matter of the Earth (biogeochemical aspects of the problem) // Geokhimiya. 1988. №2.pp. 292-306.

15. Kabata-Pendias A., Pendias H. Biogeochemia Pierwlastkov Sladowych. Warzsawa: Wydawnictwo Naukowe PWN, 1999. $400 \mathrm{~s}$.

16. Markert B., Fränzle S., Wünschmann S. Chemical Evolution: The Biological System of the Elements. Springer International Publishing, Switzerland, 2015. - 295 p.

17. Il'in, V.B. Mikroelementy i tyazhelyye metally v pochvakh i rasteniyakh / V.B. Il'in, A.I. Syso. - Novosibirsk: izd-vo SO RAN, 2001. - 229 p.

18. Kopylova L.V. The accumulation of iron and manganese in the leaves of woody plants in the technogenic regions of the Trans-Baikal Territory // Izvestiya Samarskogo nauchnogo tsentra Rossiyskoy akademii nauk. 2010.Vol.12, № 1-3. pp. $709-712$.

19 Ilyin V.B., Stepanova M.D. Protective capabilities of the soil-plant system under contaminated soil TM // TM v okpyzhayushchey cpede. - M.: MGU, 1986. - pp.80-85.

20. Podluzhnaya A. S. Akkumulyatsiya tyazhelykh metallov v pochve i drevesnykh kul'turakh rekreatsionnykh zon g. Krasnoyarska. - avtoreferat dis. ... kan-ta biol. nauk: 03.02.08 / Podluzhnaya A.S. - Tyumen', 2019. - 18p. 